\title{
Bir Günlüğüne Matematik Öğretmeni Olsaydım, Neler Yapardım/Yapmazdım: Öğrenci Görüşleri
}

\author{
Kemal Altıparmak $^{*}, \quad$ Mehmet Ali Aklar ${ }^{* *}$ Gürcan Dursun ${ }^{* * *}$
}

Öz: Bu araştırmanın amacı 5.,6.,7. ve 8. sınıf öğrencilerinin matematik dersine ve matematik öğretmenlerine yönelik düşüncelerinin ortaya çıkarılmasıdır. Araştırma 2015-2016 EğitimÖğretim yılında Ege Bölgesi’nde rastgele seçilmiş iki ortaokulda okuyan 138 adet 5,6,7 ve 8. sınıf öğrencisi ile yapılmıştır. Bu amaçla araştırmada veri toplama aracı olarak öğrencilere alan uzman görüşleri doğrultusunda hazırlanan "Bir günlüğüne matematik dersi öğretmeni olsaydım bunları ... yapardım. Bunları... yapmazdım.” şeklinde bir metin verilerek boşluk olan yerleri yazılı olarak doldurmaları istenmiştir. Doldurulan formlardan elde edilen ham veriler, içerik analizi yöntemiyle çözümlenmiştir. Bu çözümleme sonucunda öğrencilerin sırasıyla öğretmen, öğretim yöntemleri ve matematiğe karşı tutum ile ilgili görüşleri belirlenmiştir. Çalışmanın en belirgin sonuçlarından bazıları öğrencilerin matematiğe karşı güvenlerinin artırmalarına yardımcı olunmas1; matematik dersinin oyunlarla anlatılmas1; bireysel farklılıkların dikkate alınması; pekiştireç kullanılması; konu anlatımı tekrarı yapılması; matematiğin korkulan bir ders olması ve öğrencilerin sınav kaygısı taşımalarıdır.

Anahtar Kelimeler: Matematik öğretmeni, öğrenci görüşleri, matematiğe karş1 tutum, öğretmen etkililiği.

\footnotetext{
*Ege Üniversitesi, Eğitim Fakültesi, Temel Eğitim Bölümü, kemal.altiparmak@ege.edu.tr_Bornova/İzmir.

*** Milli Eğitim Bakanlığı, Matematik Öğretmeni, Çiğli/İzmir.

**** Milli Eğitim Bakanlığı, Özel Eğitim Öğretmeni, Bornova/İzmir.
}

$\begin{array}{lll}\text { Gönderim:16.02.2017 } & \text { Kabul:12.07.2017 } & \text { Yayın:15.09.2017 }\end{array}$ 


\section{If I Were a Mathematics Teacher for a Day, I would / I would not Do: Student Opinions}

Abstract: This research is aimed at revealing the thoughts of the 5th, 6th, 7th and 8th grade students about their math course and mathematics teacher. The study was carried out with 138 students in 5th, 6th, 7th and 8th grades who attended two secondary schools randomly selected in Aegean Region during the academic year of 2015-2016. For this purpose, as data collection tool in the research, it was prepared with the opinions of the experts; "If I were to teach a mathematics course for a day, I would... not do them ... ". The raw data obtained from the filled forms were analyzed by content analysis method. As a result of this analysis, students' opinions about their attitudes towards teachers, teaching methods and mathematics were determined respectively. Some of the most obvious results of the study are helping students to increase their confidence in mathematics; teaching mathematics with games; taking into account individual differences; reinforcement use; subject narration to be made a repetition; math is a feared lesson, and students are worried about testing.

Key Words: Mathematics teacher, student opinions, mathematics course, student perceptions, teacher effectiveness. 


\section{Giriş}

“5, 6, 7, 8. sınıf matematik dersi öğretim programı, öğrencilerin yaşamlarında ve sonraki eğitim aşamalarında gereksinim duyabilecekleri matematiğe özgü bilgi, beceri ve tutumların kazandırılmasını amaçlamaktadır. Bu öğretim programı matematik öğrenmeyi etkin bir süreç olarak ele almakta, öğrencilerin öğrenme sürecinde aktif katılımcı olmalarını vurgulamakta ve dolayısılla kendi ögrrenme süreçlerinin öznesi olmalarını ön görmektedir” (Milli Eğitim Bakanlığı, 2013). Milli Eğitim Bakanlığı'nın 2013 de yayınladığı “Ortaokul Matematik Dersi (5.,6.,7.,8. sınıflar) Öğretim Programı’n da” matematik öğretiminin amaçları öğrencilerin matematiksel kavramları istenilen normda kazanması, matematiğe karşı olumlu tutum ve özgüvenin artması ve kazandığı matematiksel bilgiyi hayatta kullanması şeklinde üç kategoride düşünülebilir. Bu programda öğrencinin kazanması gereken beceriler ise "problem çözme; matematiksel süreç becerileri (iletişim, akıl yürütme, ilişkilendirme); duyuşsal beceriler; psikomotor beceriler; bilgi ve iletişim teknolojileri (BİT)"dir (Milli Eğitim Bakanlığı, 2013). Amaçlar ve becerilerin gerçekleşebilmesi öğrenci, öğretmenlerin koordineli bir anlayışla çalışmalarına bağlıdır. Bunun yanı sıra öğrenme ortamı (yöntem, teknoloji, materyal, yapılandırılmış etkinlik, vb.), dersin içeriği, sınıf içi stres, kaygı gibi durumlar da amaca ulaşmada rol oynamaktadırlar.

Öğrenme ortamının planlanmasında; öğrenci, öğretim esnasında kullanılan yöntem ve materyaller ile ilgili verilerin analiz edilmesi sonucunda elde edilen bulgular önemlidir (Öztürk ve Güven, 2012). Matematiği anlayabileceğine ve matematik yapabileceğine inanan öğrenciler yetiştirmek için, öğrencilerin matematik öğretmenlerini nasıl algıladıkları ve matematik öğretmenlerinden neler beklediklerini bilmenin önemli olduğu düşünülmektedir 
(Özyıldırım, Acar ve Yetkin, 2015). Öğrenci merkezli bir öğretim ortamında öğrencinin öğretmen ve dersle ilgili görüşlerinin dikkate alınması öğrencinin derse karşı ilgi ve sorumluluğunu etkileyecektir.

Öğrenme ortamının etkili belirlenmesinde kullanılan yöntem, materyaller, teknoloji gibi durumlarla birlikte, öğretimin başarısında öğretmenler birinci derecede aktif rol oynarlar. (Öztürk ve Güven, 2012). Öğretmenler sınıfa iyi yapılandırılmış etkinlikler planlayarak gelmelidirler (Milli Eğitim Bakanlığı, 2013). Öğretmenlerin akademik olarak yeterli, öğrenci farklılıklarını gözeten, öz güvenli, yeniliklere açık ve öğretme heyecanını kaybetmemiş olmaları öğretimi olumlu etkileyecektir. Şahin (1998) ve Sullivan (2008) öğrencinin matematik dersine karşı tutumlarını etkileyen nedenlerin başında öğretmenin kendisini öğrencilerine sevdirmesi geldiğini ifade etmiştir. Mokhtar, Yusof, ve Misiran (2012) öğrencilerin matematik performansının ilgi, öğretmenin rolü, akranlar ve tutuma bağlı olduğunu belirtmiştir. Öğretmenin oluşumunda yardımcı olacağı etkili öğrenme ortamları öğrencilerin başarılarını olumlu yönde etkileyecektir. Öğrenme ortamı, psiko-sosyal faktörlerin etkileşimi ile oluşan ortamlardır (Acat, 2005). Öztürk ve Güven (2012) uygun araç gereçlerin zamanında kullanılması, öğretmenlerin sınıf içerisinde tartışma ortamları hazırlamaları ve konuların yaşamla ilişkilendirilmesi öğrenme ortamını uygun bir duruma getireceğini belirtmişlerdir. Memnun ve Akkaya (2010) çalışmalarında öğrencilerin oyunlar ve etkinliklerle öğrenmeyi daha eğlenceli ve kolay gördüklerinden dolayı matematik öğretiminde yaratıcı drama, senaryo ile öğretim, oyunlarla öğretim gibi farklı öğretim yöntemlerinin kullanılmasının uygun olacağını belirtmektedirler.

Öğrenci başarısını etkileyen etmenlerden birisi de matematiksel kaygıdır. Matematiksel kaygı, matematik ile ilgili etkinliklerde gerilim, kaygı, çaresizlik ve zihinsel 
düzensizlik olarak tanımlanmaktadır (Richardson ve Suinn, 1972; Ashcraft ve Faust, 1994). Birçok çalışmada matematiksel kaygı ile matematiksel başarı arasında negatif ilişki bulunmuştur (Ramirez, 2013; Betz, 1978; Hembree, 1990; Skiba, 1990). Matematiksel kayg1 zayıf matematik başarı ile ilişkilidir (Ashcraft \& Krause, 2007). Zakaria, (2012) matematiksel kaygının öğrencinin başarısını etkilediğini söylemişlerdir. Matematiksel kaygı taşıyan öğrenciler istenilen düzeyde matematik bilgisi edinememekte ve edindikleri matematiksel bilgileri anlamadan, özümsemeden ve kavramadan, ezberleme yoluna gidebilmektedirler (Iş1k, vd, 2008). Hendel (1980) matematiksel oyun oynayan öğrencilerin matematik kayg1 düzeylerinin matematiksel oyun oynamayan öğrencilerin kaygı düzeylerinden anlamlı olarak daha düşük olduğunu belirtmiştir. Yenilmez ve Özabacı (2003) matematik kaygı ortalamaları ile matematik tutum ortalamaları arasında anlamlı bir ilişki olduğunu ifade etmişlerdir. Öğrencilerin matematik dersine dönük başarısızlıklarının temelinde derse yönelik olarak geliştirdikleri olumsuz tutumlar yatmaktadır (Yenilmez ve Özabacı, 2003).

Şenol, vd (2015) öğrencilerin matematiğe yönelik ilgisizlikleri ve korkularının nedenleri çevre, öğretmen, öğrenci ve ders içeriği kategorileri altında sınıflandırmışlardır. Yapılan çalışmanın neticesinde öğretmenlerin büyük bir kısmı öğrencilerin matematik korkusuna sahip olduğu yönünde görüş bildirmiş olup, buna sebep olarak başta öğrencinin kendisinden kaynaklanan nedenlerin geldiği, sonrasında ders içeriği, öğretmen ve çevresel faktörlerin etkili olduğu şeklinde sonuçlar elde etmişlerdir. Öğrenciden kaynaklanan nedenler özgüven eksikliği, konuya karşı hazır bulunuşluk, kaygı ve matematiğe karşı önyargı olarak sınıflamışlardır. Öğretmenden kaynaklanan nedenler öğretmenin tutumu, pedagojik bilgisi ve mesleki bilgisi olarak belirtmişlerdir. Çevresel faktör olarak aile ve okul-sınıf ortamı gibi 
durumları elde etmişlerdir. Ders içeriğinin yoğun olması öğrencilerde bıkkınlığa neden olduğu sonucunu çalışmalarında ifade etmişlerdir.

Özçakır, vd. (2015) öğretmen adayları ile yaptı̆̆ı çalışmalarında, öğretmen adaylarının daha önceki dönemlerde matematik korkularının olduğunu ifade etmiş ve bu korkuların sebebinin genellikle ilköğretim ya da lise dönemlerindeki matematik öğretmenlerinden kaynaklandığını belirtmişlerdir. Ayrıca öğrencilerin kendi tutumlarının da matematik kaygısında etkili olduğunu belirtmişlerdir.

Memnun ve Akkaya (2010) çalışmalarında öğrencilerin matematik dersini sevdikleri fakat onların matematik dersi hakkında beklenti ve isteklerinin tam olarak karşılanmadığ sonucunu elde etmişlerdir. Öğrenciler derslerin daha zevkli hale getirilmesini, daha kolay ve anlaşılır konular işlenmesini, daha kolay sorulara yer verilmesini ve her derste yeni bir konu işlenmesini istemişlerdir. Derslerde matematikle ilgili oyunlar öğretilmesini, daha fazla etkinliklerin yapılması, günlük yaşamla ilişkilendirilmesi, teknoloji kullanılması ve daha az yazı yazıp daha fazla soru çözülmesi öğrenciler tarafından beklenmektedir. Ayrıca öğrenciler matematik öğretmeninden sınıflarında daha fazla sessizliğin sağlanmasını ve daha iyi notların verilmesini istemişlerdir (Memnun ve Akkaya, 2010).

Etkili bir programın dayanaklarından biri de öğrencidir (Ertürk, 1986). Öğrencilerin matematiğe yönelik görüşlerinin ve başarı veya başarısızlıklarını nelere bağladıklarının gözlenmesi, ülkemizde matematik başarısını artırmak adına önemlidir (Mumcu, vd., 2012). Öğrencilerin matematik öğretmenlerinden ve matematik dersi için hazırlanan öğrenme ortamından beklenti ve görüşlerinin dikkate alınması onların akademik başarı yanında tutumlarını da olumlu yönde etkileyebilir. Ayrıca yeni ilköğretim programlarıyla birlikte içerik, öğrenme-öğretme süreci ve değerlendirme aşamalarında önemli değişikliklere 
gidilmiştir ve bu değişikliklerin istenilen ölçüde uygulanıp uygulanmadığını tespit etmek yeni matematik programının başarısı açısından önemlidir (Memnun ve Akkaya, 2010). Yapılan değişikliklerin amacına ulaşıp ulaşmadığını tespit etmenin birkaç farklı yolu vardır. $\mathrm{Bu}$ yollardan birisi de öğrenci görüşleridir (Memnun ve Akkaya, 2010).

$\mathrm{Bu}$ çalışmanın amacı öğrencilerin matematik dersi için öğretmenlerinden nasıl davranmaları, nasıl ders işlemeleri, hangi yöntem ve teknikleri kullanmaları ve matematiğe karşı tutumlarını ortaya çıkarmaktır. $\mathrm{Bu}$ amaçla öğrencilerden kendilerini bir günlüğüne matematik öğretmenlerinin yerine koymaları ve bunun için neler yapıp yapmayacakları istenmiştir. Çalışma sonunda elde edilecek bulguların matematik öğretmenlerinin sınıf içerisinde davranışları (ders anlatımı ve öğrencilere yönelik), matematik dersi için öğretim yöntem ve teknikleri ve matematiğe karşı tutum açısından faydalı olacağı kanaatindeyiz.

\section{Yöntem}

$\mathrm{Bu}$ çalışmada Ege Bölgesi'nde iki ortaokulda bulunan öğrencilerden kendilerini matematik öğretmeni yerine koymaları istenerek matematik öğretmeni, öğretim yöntem ve teknikleri ve matematiğe karşı tutumları betimsel olarak incelenmeye çalışılmıştır.

\section{Katılımcılar}

Bu nitel araştırma 2015-2016 eğitim-öğretim yılının ikinci yarıyılında yapılmıştır. Araştırmaya Ege Bölgesi'nde bir ilde yansız atama yoluyla seçilmiş iki devlet ilköğretim okulundan; 5,6,7. ve 8. sınıflarda öğrenim gören 138 öğrenci katılmıştır.

\section{Veri Toplama Aracı ve Süreci}

Araştırmada veri toplama aracı olarak öğrencilere alan uzman görüşleri (1 ölçme değerlendirme uzmanı, 2 matematik eğitimi uzman1) doğrultusunda hazırlanan "Bir 
günlüğ̈̈ne matematik dersi öğretmeni olsaydım bunları ... yapardım. Bunları... yapmazdım.” şeklinde bir metin verilerek boşluk olan yerleri yazılı olarak doldurmaları istenmiştir. Öğrencilerin kendi fikir ve düşüncelerini etkilememek ve düşüncelerini tam olarak yansıtmalarını sağlamak için bu metin dışında herhangi bir müdahale ya da konuyla ilgili yorum araştırmacılar tarafından yapılmamıştır. Öğrencilere kendilerine verilen metini doldurma ile ilgili zaman ve sayfa sınırlamasında bulunulmamıştır. Ayrıca öğrencilerin verilen metini kendi bilgileri doğrultusunda doldurması ve gerçeği yansıtması için sınıf matematik öğretmenleri bu çalışmaya katılmamışlardır. Geçerlik ve güvenirliği sağlamak için alan uzman görüşlerine (1 ölçme değerlendirme uzmanı, 2 matematik eğitimi uzmanı) önem verilmiş ve veriler mümkün olduğunca ayrıntılı verilmeye ve doğrudan alıntılarla tanıtılmaya özen gösterilmiştir.

\section{Veri Analizi}

Çalışmada öğrencilerin araştırmanın sorusu olan "Bir günlüğüne matematik dersi öğretmeni olsaydım bunları ... yapardım. Bunları ... yapmazdım.” formunu doldurmaları sonucunda elde edilen ham veriler, betimsel analizi yöntemiyle çözülmeye diğer bir deyişle sistematik bir hale getirilmeye çalışılmıştır. İçerik analizi sözel, yazılı ve diğer materyallerin içerdiği mesaj ve anlamın nesnel ve sistematik olarak sınıflandırılması, sayılara dönüştürülmesi ve çıkarımda bulunmaktır (Tavşancıl ve Arslan, 2001).

Çalışmada içerik analizine geçilmeden önce bu alanda ilgili literatür incelenerek, kodlar oluşturulmuştur. Daha sonra her öğrencinin kâğıdındaki cümleler ve cümle içerisindeki kelimeler teker teker incelenmiştir. Cümlelerdeki kavramsal ifadeler ortaya çıkarılmaya çalışılmıştır. İfadelere göre kodlamalar yapılmıştır. Bu kodlamaları içerisine alacak kategoriler oluşturulmuştur. Çalışmada veri analizi esnasında özelden genele doğru 
(Tümevarım) bir yol izlenmiştir. Bu çalışmada ulaşılan kategoriler aşağıdaki Tablo 1 de verilmiştir.

Tablo 1. Öğrenci cevaplarından elde edilen kategoriler

\begin{tabular}{l}
\hline Kategoriler \\
\hline Öğrenciye yönelik tutuma ilişkin görüşler \\
\hline Ders işlenişine ilişkin görüşler \\
\hline Yöntem ve tekniklerine iliş̧in görüşler \\
\hline Matematiğe karşı tutuma ilişkin görüşler \\
\hline
\end{tabular}

Kodlamanın güvenilirliği için bu alanda iki uzman araştırmacı birbirlerinden bağımsız kodlama yapmıştır. Daha öncesinde bu iki araştırmacı ilgili literatürden temel kategori ve kodları birlikte analiz ederek kategorileri ve kodları bu çalışma için oluşturmuşlardır. Kodlamanın güvenilirliği ((Görüş birliği /(Görüş birliği+Görüş ayrıllğı)) formülü ile hesaplanmıştır (Miles ve Huberman, 1994). Çalışmada kodlamalar sırasında başlangıçta \%86 görüş birliğine varılmıştır. Daha sonra tekrar iki araştırmacının birlikte uyuşmayan kodlamaların kontrolüyle \%100 görüş birliğine varılmıştır. Çalışmanın verilerinin analizi doğrultusunda üç ana başlık oluşturulmuştur. Bunlar sırasıyla öğretmen, öğretim yöntem ve teknikleri ve matematiğe karşı tutum ile ilgili görüşlerdir.

\section{Bulgular ve Yorumlar}

$\mathrm{Bu}$ bölümde öğrencilerden elde edilen verilerin analizi ışığında öğrencilerin; öğretmen, öğretim yöntem ve teknikleri ve matematiğe karşı tutum ile ilgili görüşleri sunulmuştur.

\section{Öğretmen ile İlgili Görüşler}


Çalışmaya katılan öğrencilerin araştırma metinine verdikleri cevaplar iki bölüme ayrılmıştır. Bunlardan birincisi öğrenciye yönelik tutuma ilişkin görüşler, ikincisi ders işlenişine ilişskin görüşleridir. Öğretmenin öğrenciye yönelik tutumuna ilişkin görüşler aşağıda Tablo 2 de sunulmuştur.

Tablo 2. Öğrenciye Yönelik Tutuma İlişkin Görüşler

\begin{tabular}{lcc}
\hline Görüşler & Kişi & Yüzde \\
& sayısı & \\
\hline Öğrencilerin matematiğe karşı güvenlerini artırmalarına yardımcı olmalıdır. & 27 & 18,62 \\
\hline Öğrencilere arkadaş gibi yaklaşılmalıdır. & 6 & 4,13 \\
\hline Yanlı̧̧ cevaplara olumsuz tepki verilmemelidir. & 3 & 2,06 \\
\hline Öğrencilere rehberlik yapılmalıdır. & 1 & 0,68 \\
\hline Öğrencilere baskı yapılmamalıdır. & 4 & 2,75 \\
\hline Ceza verilmelidir. & 24 & 16,5 \\
\hline
\end{tabular}

Çalışmaya katılan öğrencilerin \%18,62’si kendilerini bir günlüğüne matematik öğretmeni yerine koyduklarında öğrencilerin matematiğe karşı güvenlerini artırmalarına yardımcı olmaya çalışacaklarını ifade eden cümleler kullanmışlardır. Bu çalışmada bu duruma ait bazı örnek öğrenci cümleleri şu şekildedir. “Onlara her konunun üstesinden gelip anlayabileceklerini söylerdim.”; “Onlara matematik dersinden korkmamalarını, bu dersin öğrendikçe basit ve eğlenceli geleceğini söylerdim.” Öğrencilerin öğretmenlerin den matematik dersine karşı cesaretlendirilmeye ihtiyaçları olduğu söylenebilir. Çalışmaya katılan öğrencilerin \%4,13’ü öğrencilerine arkadaş gibi davranacaklarını belirtmişlerdir. Buna ait bir öğrenci cümlesi şöyledir: “Onlarla sorunları oldukları zaman konuşur, fikir alışverişi yaparak yardımcı olurdum.” Bu öğrencilerin öğretmenlerinden kendileri ilgilenmelerini ve onlara bir birey oldukları hissini uyandırmaları istenmektedir denebilir. Öğrencilerin 
\%2,06'sı sorulara karşı verilen yanlış cevaplara karşı olumsuz tepki vermeyeceklerini belirtmişlerdir. Öğrencilerin \%0,68'i rehber öğretmen olacağını ifade etmişlerdir. "Derslerde ara ara öğrencilerle konuşur, onların motive olmalarını sağlardım.”; “Okulun yanına motivasyon evi gibi bir şey yaparım, çünkü çocukların motivasyonu çökerse en iyi bildiklerini bile unutur." Şeklinde cümleler belirtmişlerdir.\%2,75'i öğretmen tarafından öğrencilere uygulanan baskının, öğrencinin derse ve öğretmene karşı olumsuz bir tutum geliştirmesine neden olacağını belirtmişlerdir.

Araştırmaya katılan öğrencilerin \%16.5'i matematik öğretmeni olmaları durumunda ceza vereceklerini belirtmişlerdir. Bu görüşe sahip öğrencilerinin bazılarının kağıtlarında "Sınıf kurallarına uymayanlara cezalar verirdim.”; “Öğrenci ödevlerini yapmazsa ailesini çağırır ve ona ceza vermesini söylerim.”; "Derste konuşanları sınıftan atardım, çünkü kimsenin hakk1 yenmemeli." gibi cümleler mevcuttur. Dersi dinlemeyen, ödevini yapmayan, dersin akışını bozan ya da derse geç gelen öğrencileri uyararak, bağırarak ya da sözlü notlarını düşlük vererek cezalandıracaklarını ifade etmişlerdir. $\mathrm{Bu}$ öğrencilerin sınıf yönetiminden şikâyetçi olduğu söylenebilir.

Tablo 3. Ders İşlenişine İlişkin Görüşler

\begin{tabular}{lcc}
\hline \multicolumn{1}{c}{ Görüşler } & Kişi sayısı & Yüzde \\
\hline Dersi oyunla anlatılmalıdır. & 42 & 28,09 \\
\hline Tam öğrenme gerçekleştirilmelidir. & 31 & 21,37 \\
\hline Bireysel farklılıklar dikkate alınmalıdır. & 28 & 19,03 \\
\hline Ödev verilmelidir. & 15 & 10,34 \\
\hline
\end{tabular}




\begin{tabular}{lll}
\hline Ders anlatımı esnasında güler yüzlü olunmalıdır. & 13 & 8,96 \\
\hline $\begin{array}{l}\text { Ders anlatımı esnasında esprili olunmalıdır. } \\
\text { Konuyu anlamada zorluk yaşayan öğrencilerle birebir }\end{array}$ & 11 & 7,16 \\
çalışılmalıdır. & 9 & 7,58 \\
\hline $\begin{array}{l}\text { Matematiksel kavramların daha iyi kavranması için gerekli } \\
\text { görülen durumlarda aile ile işbirliği yapılmalıdır. }\end{array}$ & 6,20 \\
\hline Öğrencilere fırsat eşitliği sağlanmalıdır. & 8 & 5,51 \\
\hline Öğrencilerin hazır bulunuşlukları dikkate alınmalıdır. & 5 & 3,44 \\
\hline Ders esnasında müzik kullanılmalıdır. & 1 & 0,68 \\
\hline
\end{tabular}

Tablo 3 de çalışmaya katılan öğrencilerin \%28,09’u derste oyunların kullanılması kavramların daha iyi anlaşılması için faydalı olacağını düşünmektedirler. Bu öğrencilerden bazılarının cümleleri şu şekildedir. "Soruları oyun şeklinde çözerdim."; "5 saatlik dersin 3 saatinde konuyu işler, kalan iki saatlik sürede konuyu oyun haline döker süreyi öyle kullanırdım.”; "Öğrenme zorluğu çekenler için sınıfa matematik oyunları getirirdim.” Öğrencilerin \%21,37’si öğrencilerde tam öğrenmeyi gerçekleştirmek istedikleri görüşmüştür. Tam öğrenmeyle söylenmek istenilen konuyu sınıfta herkesin öğrenmesidir. Bu konuda bazı öğrenci cümleleri şöyledir. “Öğrencilerimin anlamadıkları yer varsa anlayana kadar anlatırdım.”; “Öğrenci anlamazsa konuyu baştan itibaren tekrar anlatırdım.” Öğrencilerin \%19,03'ü matematik öğretmeni olmaları durumunda öğrencilerin bireysel farklılıklarını göz önüne alacaklarını ifade etmişlerdir. Bu konuda bir öğrenci cümlesi şöyledir. "Her öğrencinin farklı bir öğrenme yeteneği vardır." Sınıftaki farklı seviye gruplarına farklı kurs saatleri ayarlayacaklarından ve her gruba göre çeşitli etkinlik ve konu anlatımında bulunacaklarından söz etmişlerdir. Öğrencilerin \%10,34’ü öğrencilere ödev verilmesinin faydalı olacağını 
düşünmektedirler. Öğrencilerin \%8,96’sı öğretmenin ders sırasında güler yüzlü ve 1lımlı olmasını istemiştir. Bu konuda bir cümle şöyledir. "Sınıfa gülerek girerdim.” Öğrencilerin \%8,16's1 ders esnasında esprili bir öğretmen olacaklarını belirtmişlerdir. Bir öğrenci bu konuda şöyle demiştir. "Dersimi eğlenceli şekilde esprili, şakalı şekilde anlatırdım, çünkü öğrencilerin dikkatini çeker ve ders eğlenceli olur.” Öğrencilerin \%7,58’i öğretmenin derste zorluk yaşayan öğrencilerle birebir ilgilenmesi gerektiğini belirtmişlerdir. Bir öğrenci bu konuda şöyle demiştir. "öğrenme zorluğu yaşayan öğrencimle ders dışında zaman ayırırdım.” Öğrencilerin \%6,20'si matematiksel kavramların daha iyi kavranması için gerekli görülen durumlarda aile ile işbirliği yapacaklarını belirtmişlerdir. Bu durum çalışmaya katılan öğrencilerin, veli-öğrenci-öğretmen iş birliğinin ne denli önemli olduğunun farkında olduklarının göstergesidir. Öğrencilerin \%5,51’i öğrencilere fırsat eşitliği verilmesi düşüncesini paylaşmışlardır. Öğrencilerden bazılarının cümleleri şu şekildedir. “Öğrenci ayırmam, hepsine eşit davranırdım.”; "Matematiği anlayanla anlamayan arasında ayrım yapmazdım, çünkü her öğrenciye eşit davranılırsa matematiği herkes sever.” Öğrencilerin \%3,44'ü öğretmenin hazır bulunuşlukları dikkate alması gerektiğini belirtmişlerdir. Öğrencilerin \%0,68'i derste müzikle beraber anlatım yapacaklarını ifade etmişlerdir.

\section{Öğretim Yöntem ve Tekniklerine İlişkin Görüşler}

Öğrencilerin, öğretim yöntem ve tekniklerine ilişkin görüşleri Tablo 4 de sunulmuştur.

Tablo 4. Öğretim Yöntem ve Tekniklerine İlişkin Görüşler

\begin{tabular}{llc}
\hline \multirow{2}{*}{ Görüşler } & Kişi sayısı & Yüzde \\
\hline Pekiştireç & 26 & 17,93 \\
\hline Konu tekrarı yapılmalıdır. & 23 & 15,86 \\
\hline
\end{tabular}




\begin{tabular}{lcc}
\hline Bol soru çözülmelidir. & 14 & 9,65 \\
\hline $\begin{array}{l}\text { Teknolojik araç gereçler(bilgisayar,projeksiyon..vb.) } \\
\text { kullanılmalıdır. }\end{array}$ & 13 & 8,96 \\
\hline Materyal kullanılmalı & 9 & 6,20 \\
\hline Modellemelerden yararlanılmalıdır. & 6 & 4,13 \\
\hline Proje ödevlerine yer verilmelidir & 5 & 3,44 \\
\hline Günlük hayatla ilişki kurulmalıdır. & 1 & 0,68 \\
\hline
\end{tabular}

Tablo 4 de çalışmaya katılan öğrencilerin \%17,93’ü matematik öğretiminde pekiştireç kullanmanın önemine değinmiştir. "Öğrencilerime küçük ödüller verirdim.” Öğrencilerin \%15,86’sı konu bittikten sonra işlenen konuların dönem içerisinde farklı zamanlarda aralıklar ile tekrar edilmesi gerektiğini ifade etmiştir. Öğrencilerin \%9,56’s1 bol soru çözülmesi düşüncesindedirler. Öğrencilerden bazılarının cümleleri şu şekildedir. "Matematik öğretmeni olsaydım çok örnek çözmek isterdim.”; “Çözebildiğim kadar örnek çözerdim.” Öğrencilerin \%8,96'sı matematik dersinde çeşitli teknolojik araç gereçlerin kullanılması gerekliliğinden bahsetmiştir. "Konuyu anlatırken teknolojiden yararlanır, akıllı tahtadan yararlanarak resimli görüntülü anlatımı kullanırım.”; "İnternetten o konuyla ilgili videolar izletirdim.”; “Akıllı tahtayı kullanarak zamandan tasarruf sağlayarak, teknolojiye ayak uydurarak çocukların derse odaklanmasını sağlardım.” Araştırmaya katılan öğrencilerin \%6,20'si matematik dersinde çeşitli materyallerin kullanılması gerektiğini belirtmişlerdir. Bir öğrenci bu konuda şöyle demiştir. "Modellemeleri, çizimleri uygulamalı olarak gösterirdim.” Öğrencilerin özellikle geometrik şekil ve cisimler, tam sayılar gibi soyut konularda bunları modelleyen materyallere dokunarak bir yaşantı oluşturmaları öğrenme ve kalıcılık oranlarında ciddi artışlara sebep olabilir. Öğrencilerin \%4,13’ü ders anlatımı sırasında modellemelerin kullanılmasının faydalı olacağ1 görüşündedirler. Öğrencilerin $\% 3,44^{\prime}$ ü proje temelli öğrenme metodunun 
kullanılmasının faydalı olacağını düşünmektedir. Öğrencilerin yalnızca \%0,68'i günlük hayatla ilişki kurulmasının önemini vurgulamıştır. Bu ise öğrencilere matematiği günlük hayattan ne kadar kopuk ve farklı bir alanmış gibi anlattığımızın göstergesi niteliğindedir.

\section{Matematiğe Karşı Tutuma İlişskin Görüşler}

Çalışmaya katılan öğrencilerin matematik dersine karşı tutum ile ilgili görüşleri Tablo 5 de verilmiştir.

Tablo 5. Matematiğe karşı tutum ile İlgili Görüşler

\begin{tabular}{lcc}
\hline Görüşler & Kişi sayısı & Yüzde \\
\hline Matematik korkulan bir derstir. & 36 & 24,82 \\
\hline Sınav kaygısı taşıyorum. & 21 & 14,48 \\
\hline Matematik öğretmeni olsam istifa ederdim, matematikten & 15 & 10,34 \\
nefret ediyorum. & & \\
\hline Ders çok sıkıcıdır. & 8 & 5,51 \\
\hline Ders yorucu ve zordur. & 6 & 4,13 \\
\hline Sinıf ortamı düzenlenmelidir. & 4 & 2,75 \\
\hline Matematik gereksiz bir derstir. & 2 & 1,37 \\
\hline Konu sayısı çok fazladır. & 2 & 1,37 \\
\hline
\end{tabular}

Tablo 5 de çalışmaya katılan öğrencilerin \%24,82'si matematik dersinin öğrenciler tarafından korkulan bir ders olduğunu belirtmişlerdir. Öğrencilerden bazılarının cümleleri şu şekildedir. "Çocuklar sınavlardan korkmasın diye sınavları kolay yapardım.”; “Öğrencilerin matematik korkularını düzeltmeye çalışırdım.” Bu bulgunun karşılaşılma yüzdesi ile yukarıda bahsedilen öğrencilerin cesaretlendirilmesi gerekliliği ile ilgili olan bulgunun karşılaşılma yüzdeleri benzerlik göstermektedir. Bu da bizlere öğrencilerin korkularını yenmeleri için, öğretmenlerinin rehberliği ve kontrolünde yaşantılar deneyimlemesi gerekliliğini 
göstermektedir. Öğrencilerin \%14,48’i matematik sınavlarına girerken kaygı duyduklarını belirtmişlerdir. Bu konuda bir cümle şöyledir. "Sınavda alakası olmayan yerlerden sormaz, deftere yazdırdığım örneklerin benzerlerini sorardım.” Dersten başarısız olma kaygısı ve aile tarafından gelebilecek tepkilerin korkusu, öğrencilerde sınav kaygısı oluşmasına neden olabilir. Öğrencilerin \%10,34’ü matematik dersini sevmediklerini ve matematik öğretmeni olsalar bile istifa edeceklerini belirtmişlerdir. Öğrencilerden bazılarının cümleleri şu şekildedir. "İstifa ederdim. Matematiğim iyi olsa da çok sıkıcı bir ders.”; "Olmazdım çünkü matematikten nefret ediyorum." Yine öğrencilerin \%5,51’i dersin çok sıkıcı olduğunu, \%4,13'ü dersin yorucu ve zor olduğunu, \%1,37'si konuların çok uzun olduğunu, yine \%1,37'si dersin gereksiz olduğunu düşünmektedirler. Bir öğrenci bu konuda şöyle demiştir. "Matematik dersi 4 işlem haricinde gereksizdir." Öğrencilerin matematik dersinin zor olduğunu düşünmeleri ve dersten sıkılmaları onları matematik dersine karşı ilgilerini etkilemektedir. Konuyla ilgili bir cümle şöyledir. "Matematik öğretmeni olmazdım, çünkü matematik zor bir ders." Öğrencilerin $\% 2,75$ 'i sınıf ortamının düzenlemesi gerektiğini düşünmektedir.

\section{Sonuç ve Tartışma}

Çalışma kapsamında Ege Bölgesi'nde bulunan, iki farklı ortaokulda 5 ile 8. sınıflar arasında öğrenim gören 138 öğrenciye "Bir günlüğüne matematik öğretmeni olsam ..... yapardım/yapmazdım" ifadesinin yer aldığı anketler dağıtılarak, öğrencilerin matematik öğretmeni, öğretim yöntemi ve matematiğe karşı tutum hakkındaki fikirleri elde edilmeye çalışılmıştır. Toplanan anketlerden elde edilen veriler ile ana ve alt kategoriler oluşturulmuştur. Anketlerin analiz edilmesi sürecinde ise öğrencilerin yazdıklarının beklentileri aştığı gözlemlenmiştir. Eğitim yöntemleri hakkında herhangi bir eğitimleri 
olmamasına karşın öğrencilerin 5 ile 8 yıl arasında değişen öğrencilik tecrübelerine dayanarak birçok eğitim modeli ile benzerlik gösteren tespitlerde bulunmuşlardır. $\mathrm{Bu}$ çalışmada ki öğrencilerin adeta usta-çırak ilişkisinde olduğu gibi her karşılaştıkları öğretmenleri dikkatli şekilde izleyip, analiz ettikleri izlenmiştir. Öğretmeninin sahip olması gereken özellikler belirlenirken çok iyi gözlemciler olan öğrencilerin de fikrinin alınması bu alana katk1 sağlayacaktır.

$\mathrm{Bu}$ çalışmaya katılan öğrencilerin görüşlerinde en yüksek oranda belirtilen ilk altı bulgu sirasıyla dersi oyunlarla anlatacakları $(\% 28,04)$, matematiğin korkulan bir ders olduğu $(\% 24,82)$, öğrenmeyi gerçekleştirecekleri $(\% 21,37)$, bireysel farklılıkları dikkate alacakları (\%19,03), öğrencilerin matematiğe karşı özgüvenlerini artırmalarına yardımcı olacakları $(\% 18,62)$, ve pekiştireç kullanacakları $(\% 17,93)$ dır. Benzer bulgulara literatürde de rastlanmıştır. Memnun ve Akkaya (2010) çalışmasında öğrencilerin matematik derslerinde oyunlar yardımıyla konuların işlenişini istediklerini belirtmişlerdir. Çakır (2009) bireysel farklılıkların dikkate alınması gerekliliğini çalışmasında vurgulamıştır. Zakaria ve Norazah (2008)'nin çalışmalarında matematik derslerinin korkulan ders olduğunu elde etmişlerdir. Bu bulgular 1şı̆̆ında öğrencilerin çoğunun matematik dersini zor bir ders olarak gördükleri anlaşılabilir. Bu sebepten dolayı öğretmenlerinden kendilerini rahatlatmalarını ve kendilerine destek olmalarını beklemektedirler. Dersin oyunlarla anlatılması sayesinden dersin korkutucu etkisinin azalacağını ve daha iyi öğreneceklerini düşünmektedirler. Öğretmenin kullanacağı pekiştireçler öğrencilerin hem kendilerine olan özgüvenleri artıracak ve dersin korkutucu etkisini azaltacaktır. Öğrencilerin matematik dersinde motivasyonlarını üst düzeyde tutmak için pekiştireç kullanılması gereken etkili bir öğretmen enstrümanıdır. Öğretmenler sınıftaki öğrencilerin birbirlerinden farklı deneyim ve öğrenme kapasitelerine sahip olduklarını göz önüne almalıdırlar. Öğretmenlerin pekiştireç kullanırken adil olmaları, bireysel farklılıkları 
gözetmeleri gerekmektedir. Böylece Matematik dersinde daha az etkili olan öğrencilerin derse karşı tutumları olumlu yönde etkilenecektir.

Çalışmada yüksek oranda karşılaşılan bulgular dan bazıları; konu tekrarı yapacakları $(\% 15,86)$, sınav kaygısı taşıdıkları $(\% 14,48)$, bol soru çözecekleri(\%9,65)'dir. Buradaki bulguların da birbirleriyle ilişkili olduğu söylenebilir. Öyle ki konuyu tam öğrenemeyen öğrenciler sınav kaygısı yaşarlar, bu sebeple öğretmenlerinden konuyu tekrar etmelerini ve konu ile ilgili bol bol soru çözerek de sınava yönelik kaygılarını azaltmak isteyebilirler. Cantimer ve Şengönül (2013) çalışmasında da öğrencilerin sınav kaygısı taşıdıkları bulgusuna rastlanmıştır.

Çalışmaya katılan öğrencilerin $\% 16,5^{\prime}$ i sınıfın huzurunu bozan öğrencilere ceza vereceklerinden bahsetmişlerdir. Sınıf yönetiminin etkisiz kaldı̆̆ı sınıflarda gerçekten sınıfa öğrenme isteği ile gelen öğrencilerin olumsuz etkilendiği söylenebilir. Çalışmada bu görüşü savunan öğrenciler öğrenme haklarının engellendiğini ve bunu elde etmeyi ceza terimiyle ifade etmeye çalışmış olabilirler. Fakat öğretmenin önemli görevlerinden birisi ceza vermek yerine sınıfta disiplini sağlaması olduğunu düşünmekteyiz.

Çalışmaya katılan öğrenciler öğretmenlerinin ders işlerken teknolojik araçlar kullanmasinı $(\% 8,96)$, materyaller $(\% 6,20)$ ve modellemeler $(\% 4,13)$ kullanarak konuyu somutlaştırmasını aynı zamanda günlük hayattan da $(\% 0,68)$ örnekler vermesini beklemektedir. Tankersley (1993) 4. sınıftan itibaren öğretmenlerin gerçek yaşam durumlarını ihmal ederek soyut kavramlar üzerinden dersi anlatması öğrencilerin matematiğe ilgilerini yitirmelerine sebep olmuştur. Matematik dersinde kullanılan teknolojik gereçler sayesinde derslerin sıkıcılıktan kurtarılması ve kavramların somutlaştırılması sağlanabilir. 
Çalışma grubundaki öğrencilerin görüşlerinde olumsuz yönde fikirler oldukça fazladır (Matematik korkulan bir derstir $(\% 24,82)$, sınav kaygısı taşıyorum $(\% 14,48)$, matematik öğretmeni olsam istifa ederdim, matematikten nefret ediyorum $(\% 10,34)$, ders çok sıkıcıdır $(\% 5,51)$, ders yorucu ve zordur $(\% 4,13))$. Bu görüşlerin giderilmesindeki en büyük görev ise şüphesiz matematik öğretmenlerine düşmektedir. Her öğrenciye hem kendilerini geliştirecek hem de başarabilecekleri görev vererek onları cesaretlendirmek, matematik korkusunu engelleyebilir. Ayrıca öğretmenlerinin rehber öğretmenler ile birlikte öğrencilerin sınav kaygıları hakkında çalışma yapmasında fayda görülmektedir. İyi bir matematik öğretmeninin sahip olması gereken özellikler alan bilgisi ile sınırlı olmamalıdır (Foss ve Kleinsasser,1996). Hotaman (2012) iyi bir öğretmenin iletişim becerisi yüksek, coşkulu, hoşgörülü ve sabırlı olması gerektiğine değinmiştir.

Bu çalışmaya katılan öğrencilerin bir kısmı öğrencilere baskı yapmayacaklarını, güler yüzlü ve espirili olacaklarını, sıkıcı olmayacaklarını belirtmişlerdir. Langlois ve Zales (1992) geliştirdikleri öğretmen profilinde güler yüzlü, şefkatli, enerjik, olumlu, güvenilir kavramları bu çalışmdaki öğrencilerin belirlediği öğretmen şekliyle benzerlik göstermektedir.

Çalışma bulgularına göre öğrencilerin kaliteli öğrenme ortamları hakkında farkındalıkları olduğu açıkça görülmektedir. $\mathrm{Bu}$ sebeple öğretmenlerin kendilerini değerlendirmeleri için öğrenci görüşlerine de önem vermeleri faydalı olacaktır. Öğretmenler, öğrencilerden kendileri hakkında sıklıkla geri bildirim istemeli ve bu verilere göre ders planlaması yapmalıdır. Uygulanacak ve geliştirilecek yeni yöntemler hakkındaki değerlendirmelerde öğrencilere de söz hakkı verilmesinin faydası olacağını düşünmekteyiz. Öğrenme süreçlerinde öğrencilerin de öğretmen ve uzmanlar kadar söz hakk1 olduğunu ve değerlendirmelerinin anlam ifade ettiği kanaatindeyiz. 
Öğrencilerin kendilerini matematik öğretmeni yerine koyarak duygu ve düşüncelerini araştıran bir çalışmaya rastlanmamıştır. Bu bakımdan elde edilen bulguların önem taşıdığını düşünmekteyiz. Diğer taraftan bu çalışmaya katılan öğrencilerle yüz yüze görüşmeler yapılmamıştır. Öğrenci görüşlerini daha iyi ortaya çıkarmak için yüz yüze görüşmeler yapılabilir. Böylece öğrencilerin matematik dersinden ve öğretmeninden beklentileri nedenleriyle beraber daha iyi belirlenebilir.

\section{Makalenin Bilimdeki Konumu (Yeri)}

Matematik ve Fen Bilimleri Eğitimi Bölümü /Matematik Eğitimi Anabilim Dalı

\section{Makalenin Bilimdeki Özgünlüğü}

$\mathrm{Bu}$ çalışmanın amacı ortaokul öğrencilerinin matematik dersine ve öğretmenlerine ait öğrenci görüşlerini ortaya çıkarmaktır. Bunun için 138 adet 5,6,7 ve 8. sınıf öğrencisine "Bir günlüğüne matematik dersi öğretmeni olsaydım bunları ... yapardım. Bunları... yapmazdım.” şeklinde bir form vererek görüşlerini yazmaları istenmiştir. Araştırma nitel bir çalışmadır. Öğrenci görüşlerinden elde edilen verilerin analizi sonucunda bulgular elde edilmiştir. Bu bulgular öğrenci görüşlerini yansıttığından dolayı bu alanda yapılabilecek çalışmalar için matematik dersi, matematik öğretmeni ve öğretim ortamı bakımından değerli olduğu düşünülmektedir.

\section{Kaynaklar}

Acat, B. (Eylül, 2005). Öğrenci merkezli eğitimde öğrenme ortamı boyutlarının düzenlenmesi. Sözlü bildiri, V. Uluslararası Eğitim Teknolojileri Sempozyumu. Sakarya Üniversitesi, Sakarya. 
Ashcraft, M.H. \& Faust, M.W. (1994). Mathematics anxiety and mental arithmetic performance : An exploratory investigation. Cognition and Emotion. 8, 97-125.

Ashcraft, M.H. \& Krause, J.K. (2007). Working memory, math performance and math anxiety. Psychonomic Bulletin \& Review, 14(2), 243-248.

Betz, N.E. (1978). Prevalence, distribution, and correlates of math anxiety in college students'. Journal of Counseling Psychology, 25(5):441-448.

Şenol, A., Dündar,S., Kaya, İ., Gündüz,N. ve Temel, H. (2015). Investigation of secondary school mathematics teachers' opinions on mathematics fear. Ĕ̌itimde Kuram ve Uygulama, 2015, 11(2), 653-672.

Cantimer, G.G. ve Şengönül, S. (2013). Ortaokul 6., 7. ve 8. sınıf öğrencilerinin matematik dersine yönelik kaygıları ve dersi değerlendirmeleri. International Journal of Social Science, 48, 261-282.

Çakır, İ. (2009). İlköğretim beşinci sınıf matematik ders kitaplarının öğretmen ve öğrenci görüşleri doğrultusunda değerlendirilmesi. Yayımlanmamış yüksek lisans Tezi, Çukurova Üniversitesi Sosyal Bilimler Enstitüsü, Adana.

Ertürk, S. (1986). Eğitimde program geliştirme. Ankara: Yelkentepe Yayınları.

Foss, D. H. \& Kleinsasser, R. C. (1996). Preservice elementary teachers' views of pedagogical and mathematical content knowledge. Teaching and Teacher Education, 12(4), 429-442.

Hembree, R. (1990). The nature, effects, and relief of mathematics anxiety. Journal for Research in Mathematics Education, 21(1), 33-46. 
Hendel, D. (1980). Experiential and affective correlates of math anxiety in adult women. Psychology of Women Quarterly, V (2), 219- 230.

Hotaman, D. (2012). Öğretmen Adaylarının Öğretmen Kişilik Özelliklerine Yönelik Algılarının İncelenmesi, Kuramsal Eğitimbilim Dergisi, 5(2), 186-201.

Işık, A., Çiltaş, A. ve Bekdemir, B. (2008). Matematik eğitiminin gerekliliği ve önemi, Kazım Karabekir Eğitim Fakültesi Dergisi, 17, 174-184.

Karakuş, M. ve Yeşilpınar, M. (2013). İlköğretim altıncı sınıf matematik dersinde uygulanan etkinliklerin ve ölçme-değerlendirme sürecinin incelenmesi: Bir durum çalışması. Pegem Ĕgitim ve Öğretim Dergisi, 3(1), 35-54.

Langlois, D. E. \& Zales, C. R. (1992). Anatomy of a top teacher. Education Digest, 57(5), 31-34.

Memnun, D. ve Akkaya, R. (2010). İlköğretim yedinci sınıf öğrencilerinin matematik dersi hakkındaki düşünceleri. Kurumsal Eğitimbilim Dergisi, 3(2) , 100-117.

Miles, M. B. \& Huberman, A.M. (1994). Qualitative data analysis: an expanded sourcebook. (2nd Edition). Calif. : SAGE Publications.

Milli Eğitim Bakanlığı. (2013). İlköğretim Matematik Dersi Öğretim Programı (1-5. Sinıflar), Ankara: Devlet Kitapları Basım Evi.

Mokhtar, S. F., Yusof, Z. M. \& Misiran, M. (2012). Factors affecting students' performance in mathematics. Journal of Applied Sciences Research, 8(8), 4133-4137. 
Mumcu, H., Mumcu, İ. ve Aktaş, M. (2012). Meslek liseleri öğrencileri için matematik. Amasya Üniversitesi Ĕ̆itim Fakültesi Dergisi. 1(2), 180-195.

Özçakır Sümen, Ö., Çağlayan, K. T. ve Kartal, A. (2015). Sınıf öğretmeni adaylarının matematik korkuları. Hacettepe Üniversitesi Ĕ̈itim Fakültesi Dergisi, 30(2), 69-80.

Öztürk, T. ve Güven, B. (Haziran, 2012). Etkili bir matematik öğrenme ortamının sahip olması gereken özelliklerine ilişkin öğretmen görüşleri. Sözlü bildiri, X. Ulusal Fen ve Matematik Ĕgitimi Kongresi, Niğde.

Özyıldırım Gümüş, F., Acar, T. ve Yetkin Özdemir, E. (2015). Ortaokul öğrencilerinin gözünden matematik öğretmenleri. Mehmet Akif Ersoy Üniversitesi Eğitim Fakültesi Dergisi, 34, 23-51.

Richardson, F.C. \& Suinn, R.M. (1972). The Mathematics Anxiety Rating Scala. Psychametric Data, Journal of Caunseling Psyeling, 19, 551-554.

Skiba, A.E. (1990). Reviewing an old subject: Math anxiety. Mathematics Teachers, 83, 188-189.

Sullivan, L. A. C. (2008). A Study Of Students' Perceptions About Their Attitude Toward Mathematics (Atm), Achievement In Mathematics (Alm), Factors That Influence Atm, And Suggestions To Improve Atm In A "Beter Than Average" District: Grades 4 Through 8. Doctorate Thesis, Montclair State University.

Şahin, F. (1998). Okul öncesinde fen bilgisi öğretimi ve aktivite örnekleri. İstanbul: Beta Yayım Dağıtım.

Tankersley, K. (1993). Teaching math their way. Educational Leadership, 50, 12-13. 
Tavşancıl, E. ve Arslan, A. E. (2001). Sözel, yazılı ve diğer materyaller için içerik analizi ve uygulama örnekleri (1. Bask1). İstanbul: Epsilon Yayınevi.

Yenilmez, K. ve Özabacı, N.Ş. (2003). Yatılı öğretmen okulu öğrencilerinin matematik ile ilgili tutumları ve matematik kaygı düzeyleri arasındaki ilişki üzerine bir araştırma. Pamukkale Üniversitesi Ĕ̆itim Fakültesi Dergisi, 14, 132-146.

Yıldırım, A. ve Şimşek, H. (2005). Sosyal bilimlerde nitel araştırma yöntemleri. Ankara: Seçkin.

Ramirez, G. (2013). Math anxiety, working memory, and math achievement in early elementary school. Journal of Cognition and Development, 14, 187-202.

Zakaria, N. (2012). Mathematics anxiety and achievement among secondary school stundents'. American Journal of Applied Sciences, 9(11), 1828-1832.

Zakaria, N. \& Norazah, M.N. (2008). The effects of mathematics anxiety on matriculation students as related to motivation and achievement. Eurasia Journal of Mathematics Science \& Technology Education, 4(1), 27-30. 